\title{
Study on the Corrosion Mechanism of Zn-5Al-0.5Mg-0.08Si Coating
}

\author{
Shiwei Li, Bo Gao, Ganfeng Tu, Yi Hao, Liang Hu, and Shaohua Yin \\ School of Materials and Metallurgy, Northeastern University, Shenyang, Liaoning 110004, China \\ Correspondence should be addressed to Bo Gao, ljiaojiao@163.com \\ Received 15 January 2011; Accepted 15 March 2011 \\ Academic Editor: Jianxin Zou \\ Copyright () 2011 Shiwei Li et al. This is an open access article distributed under the Creative Commons Attribution License, \\ which permits unrestricted use, distribution, and reproduction in any medium, provided the original work is properly cited.
}

A new type of hot-dip $\mathrm{Zn}-5 \mathrm{Al}-0.5 \mathrm{Mg}-0.08 \mathrm{Si}$ and $\mathrm{Zn}-5 \mathrm{Al}$ alloy coatings was performed on the cold rolled common steel. The hot-dip process was executed by self-made hot-dip galvanising simulator. SEM and EDS test results demonstrated that Mg was mainly distributed in crystal boundaries. XRD test results showed that the corrosion product of $\mathrm{Zn}-5 \mathrm{Al}-0.5 \mathrm{Mg}-0.08 \mathrm{Si}$ alloy coating was almost $\mathrm{Zn}_{5}(\mathrm{OH})_{8} \mathrm{Cl}_{2} \cdot \mathrm{H}_{2} \mathrm{O}$. The features of $\mathrm{Zn}_{5}(\mathrm{OH})_{8} \mathrm{Cl}_{2} \cdot \mathrm{H}_{2} \mathrm{O}$ are low electric conductivity, insolubility and good adhesion. The corrosion resistance of alloy-coated steels was detected by neutral salt spray test. The microstructural characterization of the coating surface after neutral salt spray test and removing the corrosion products revealed that the corrosion process of $\mathrm{Zn}-5 \mathrm{Al}-0.5 \mathrm{Mg}-0.08 \mathrm{Si}$ coating was uniform and the coating surface was almost flat. As a result, the corrosion resistance of $\mathrm{Zn}-5 \mathrm{Al}-0.5 \mathrm{Mg}-0.08 \mathrm{Si}$ coating has a remarkable improvement with a factor of 9.2 compared with that of $\mathrm{Zn}-5 \mathrm{Al}$ coating.

\section{Introduction}

Owing to excellent mechanical properties, large production, and low-cost manufacture, steels are applied widely in nearly every field, such as machinofacture, building, and dunnage. But its resistanc to atmospheric corrosion is very low in most environments [1-7]. Hot dipping is a very efficient method to protect steels from corrosion, and zinc coating can provide a barrier and galvanic protection for steel substrate $[1,2,5]$. The corrosion resistance of zinc coating can be enhanced by adding alloying elements, for example, $\mathrm{Al}, \mathrm{Mg}, \mathrm{RE}$, and $\mathrm{Ni}$ [5-12]. The effect of $\mathrm{Mg}$ element is the most remarkable among them. But detailed information on the structure and properties of the coating is limited in published literatures [4], and the reason for enhanced corrosion resistance has not yet been clarified definitely $[2,8,13]$. In this paper, the corrosion mechanism of hot-dip Zn-5Al-0.5Mg-0.08Si coating was studied in detail by the coating microstructure and corrosion products analysis.

\section{Experimental Procedures}

2.1. Materials. Purities of $\mathrm{Zn}, \mathrm{Al}, \mathrm{Mg}$, and Si were $99.99 \%$, $99.7 \%, 99.94 \%$, and $99.93 \%$, respectively. The substrate was common cold rolled steel (DC01D).

2.2. Process of Pretreatment and Hot Dipping. The process of pretreatment and hot dipping was as follows: alkaline degreasing $\left(\mathrm{NaOH}, 15\right.$ wt. \%) at $80^{\circ} \mathrm{C}$ for 5 minutes with a soft brush $\rightarrow$ water flush $\rightarrow$ remove iron oxides with $\mathrm{HCl}$ solution $\left(18\right.$ vol. $\left.\%, 70^{\circ} \mathrm{C}\right) \rightarrow$ water flush $\rightarrow$ electrolysis fuxing (the parameters was according to China patent, no. 201010296310.4$) \rightarrow$ dried at $120^{\circ} \mathrm{C}$ for 20 minutes in a oven $\rightarrow$ hot-dip. Table 1 shows some factors $[14,15]$ that affect thickness of coating in hot-dip process and the actual parameters used in this experiment.

2.3. Examination of Coatings. The surface microstructure of the coatings, the corrosion products after neutral salt pray test, and the morphology of coatings after removing the corrosion products were examined by means of scanning 
TABLE 1: Relative parameters that influence coating thickness.

\begin{tabular}{lccc}
\hline Parameters classification & Experiment parameters & Parameters classification & Experiment parameters \\
\hline Rising rate of steel & $150[\mathrm{~m} / \mathrm{min}]$ & Air pressure & $0.01[\mathrm{Mpa}]$ \\
Ingredient of alloy & $\mathrm{Zn}-5 \mathrm{Al}$ & Distance between air bells 12 knife and steel & $20[\mathrm{~mm}]$ \\
Hot-dip temperature & $\mathrm{Zn}-5 \mathrm{Al}-0.5 \mathrm{Mg}-0.08 \mathrm{Si}$ & Air bells knife angle & $-5\left[{ }^{\circ}\right]$ \\
Hot-dip time & $450\left[{ }^{\circ} \mathrm{C}\right]$ & Distance between air knife and melting zinc surface & $20[\mathrm{~cm}]$ \\
\hline
\end{tabular}

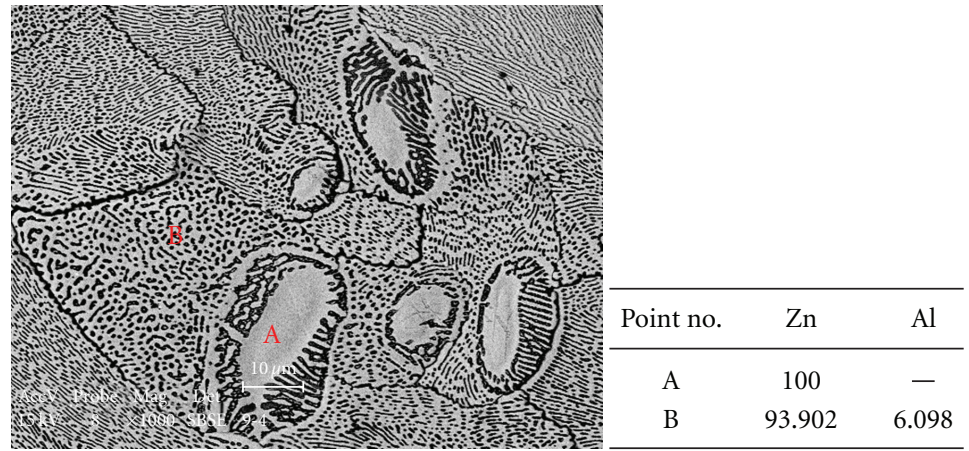

FIGURE 1: SEM image of $\mathrm{Zn}-5 \mathrm{Al}$ coating and corresponding results of EDS in A and B dots.

electron microscopy (SEM, SSX-550 equipped with EDS). The analysis of corrosion products was carried out on a PANALYTICAL X'Pert Pro MPD(PW3040/60). The neutral salt spray test was carried out by salt spray testing chamber (DCTC1200p, produced by Germany Siemens company) for 96 hours continuously. (Other parameters adopted in this study in the neutral salt spray test were according to China national standard GB/T10125-1997.)

\section{Results and discussion}

3.1. SEM and EDS Analysis of Coatings Surface. Figure 1 shows the surface morphology image of $\mathrm{Zn}-5 \mathrm{Al}$ coating and corresponding results of EDS in A and B dots. From Figure 1, it can be found that the coating consists of coarse $\beta(\mathrm{Zn})$ and $\mathrm{Zn}$-Al binary eutectic phases. Owing to the potential difference between the two phases, when the coating is put in the corrosive environment, the phase of lower electrode potential will accelerate corroding process, while the phase of higher electrode potential will be protected from corroding. So the corrosion resistance of $\mathrm{Zn}-5 \mathrm{Al}$ coating is not very high.

Figure 2 indicates SEM images of $\mathrm{Zn}-5 \mathrm{Al}-0.5 \mathrm{Mg}-0.08 \mathrm{Si}$ coating. It can be seen that the dendritic arm spacing of $\mathrm{Zn}$ $5 \mathrm{Al}$ coating is significantly decreased from $\sim 10 \mu \mathrm{m}$ to $2-5 \mu \mathrm{m}$ after adding alloying elements $\mathrm{Mg}$ and $\mathrm{Si}$; meantime, some new phases are formed expect $\beta(\mathrm{Zn})(\mathrm{A})$, such as Al-rich(B) and $\mathrm{MgZn}_{2}-\mathrm{Zn}-\mathrm{Al}$ ternary eutectic(C) [2]. Magnesium is only distributed in crystal boundaries, and it can make the grains fine and restrain the crystal boundary corrosion [16].

3.2. XRD Analysis of Corrosion Products. Figure 3 shows the XRD patterns of the corrosion products of $\mathrm{Zn}$ $5 \mathrm{Al}$ and $\mathrm{Zn}-5 \mathrm{Al}-0.5 \mathrm{Mg}-0.08 \mathrm{Si}$ coatings. As shown in Figure $3(\mathrm{a})$, the corrosion products of $\mathrm{Zn}-5 \mathrm{Al}$ are $\mathrm{Zn}(\mathrm{OH})_{2}$ and $\mathrm{Zn}_{5}(\mathrm{OH})_{8} \mathrm{Cl}_{2} \cdot \mathrm{H}_{2} \mathrm{O}$. Figure $3(\mathrm{~b})$ shows that the corrosion product of $\mathrm{Zn}-5 \mathrm{Al}-0.5 \mathrm{Mg}-0.08 \mathrm{Si}$ coating is only $\mathrm{Zn}_{5}(\mathrm{OH})_{8} \mathrm{Cl}_{2} \cdot \mathrm{H}_{2} \mathrm{O}$, so it can be concluded that the addition of $\mathrm{Mg}$ can promote the conversion process from $\mathrm{Zn}(\mathrm{OH})_{2}$ to $\mathrm{Zn}_{5}(\mathrm{OH})_{8} \mathrm{Cl}_{2} \cdot \mathrm{H}_{2} \mathrm{O}$ [17]. $\mathrm{Zn}_{5}(\mathrm{OH})_{8} \mathrm{Cl}_{2} \cdot \mathrm{H}_{2} \mathrm{O}$ with characteristics of electric conductivity, insoluble and Good adhesion $[18,19]$ can better protect the coating compared to $\mathrm{Zn}-5 \mathrm{Al}$ coating.

3.3. SEM Analysis of Morphology of Corrosion Products. Figure 4 shows SEM images of corrosion products for $\mathrm{Zn}$ $5 \mathrm{Al}$ and $\mathrm{Zn}-5 \mathrm{Al}-0.5 \mathrm{Mg}-0.08 \mathrm{Si}$ coatings. Figure 4(a) shows that the corrosion products of $\mathrm{Zn}-5 \mathrm{Al}$ coating are smooth and loose, and there are some holes on the surface, so the corrosion products cannot prevent the corrosion media from penetrating itself. Figure 4(b) indicates that the corrosion products of $\mathrm{Zn}-5 \mathrm{Al}-0.5 \mathrm{Mg}-0.08 \mathrm{Si}$ are very dense and the size of grain is very fine. Thus, it can protect the coating effectively. Therefore, it can be concluded that corrosion resistance of $\mathrm{Zn}-5 \mathrm{Al}-0.5 \mathrm{Mg}-0.08 \mathrm{Si}$ is much better than that of $\mathrm{Zn}-5 \mathrm{Al}$ coating. The related literatures [10, 20-22] have reported that the densely packed corrosion products can prevent the oxygen diffusion and improve the corrosion resistance of the coating.

3.4. SEM Analysis of Coating Surface after Removing the Corrosion Products. Figure 5 shows SEM images of the microstructure of coating surface after removing the corrosion products of neutral salt spray test. As shown in Figure 5(a), the $\mathrm{Zn}-5 \mathrm{Al}$ coating has been exfoliated during the neutral salt spray test, and many narrow cracks were found on the surface. Therefore, the corrosion media can penetrate the coating, and the corrosion rate would be 


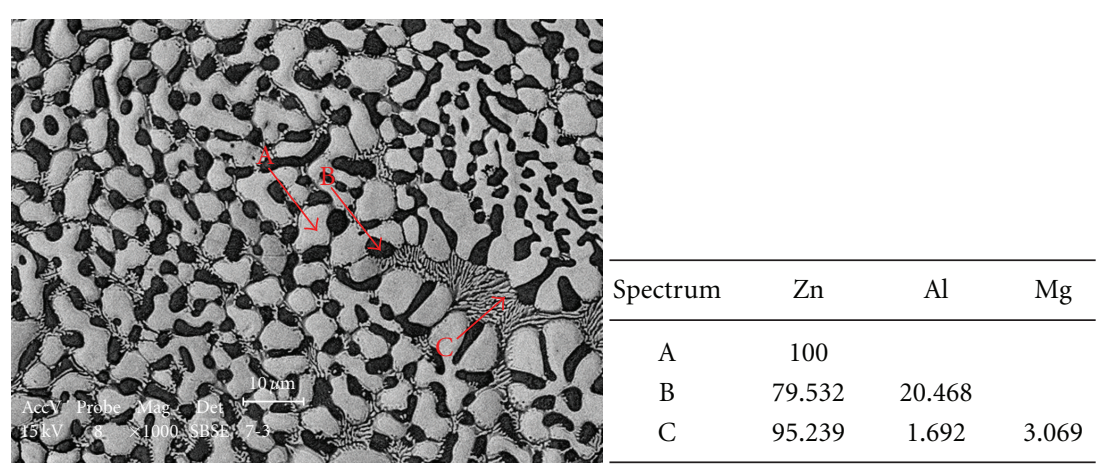

Figure 2: SEM images of Zn-5Al-0.5Mg-0.08Si coating and EDS microanalyses (composition in wt\%).

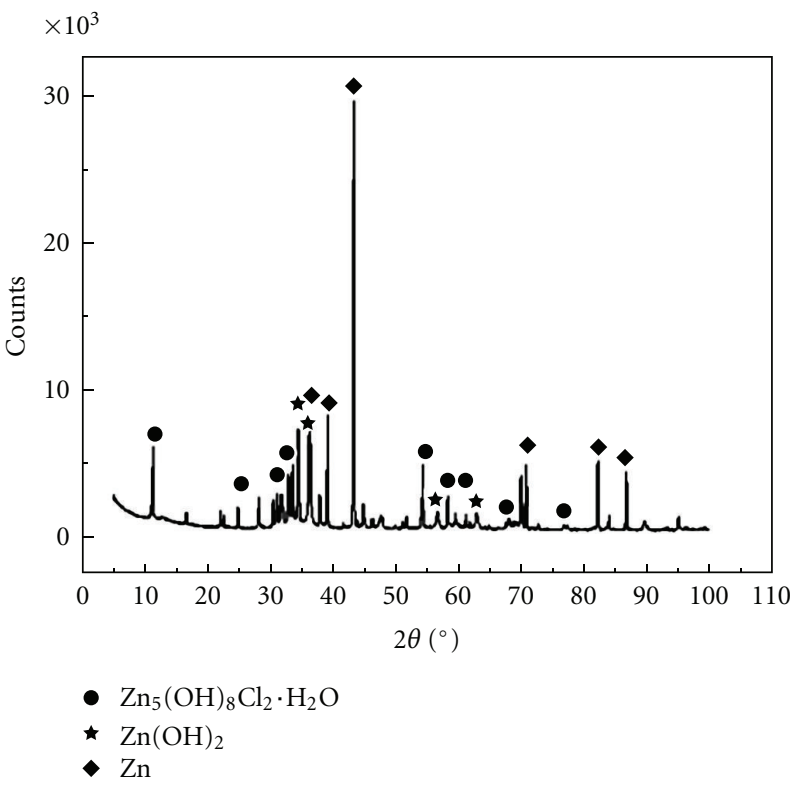

(a)

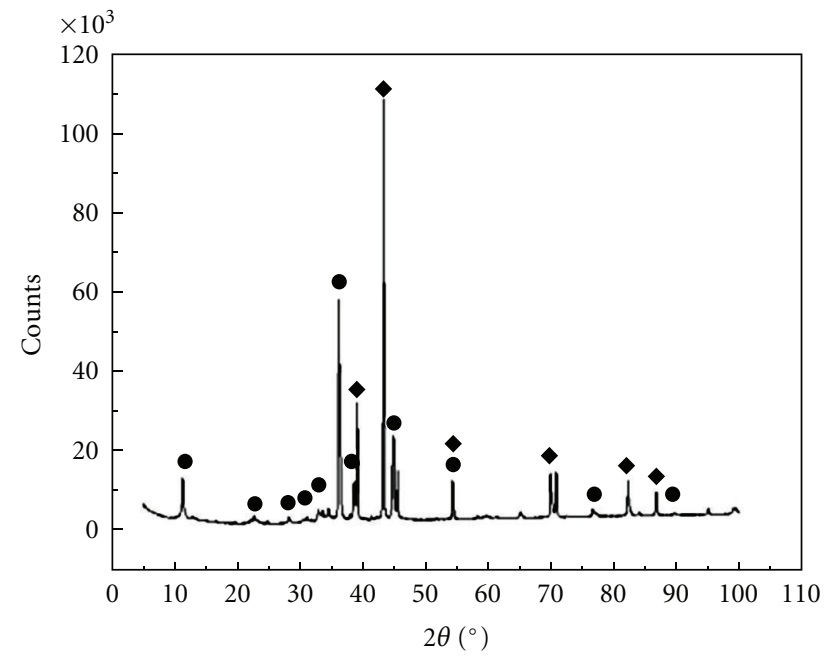

- $\mathrm{Zn}_{5}(\mathrm{OH})_{8} \mathrm{Cl}_{2} \cdot \mathrm{H}_{2} \mathrm{O}$

$\bullet \mathrm{Zn}$

(b)

FigURE 3: XRD patterns of corrosion products of Zn-5Al and Zn-5Al-0.5Mg-0.08Si coatings ((a) Zn-5Al coating, (b) Zn-5Al-0.5Mg-0.08Si coating).

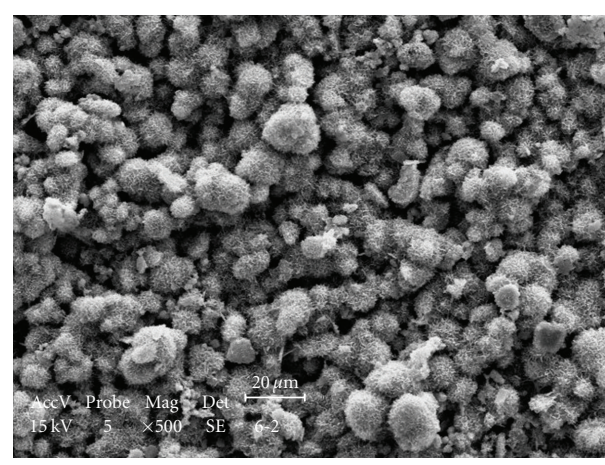

(a)

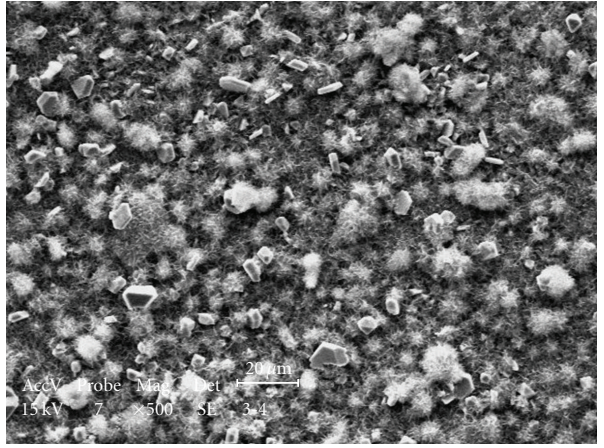

(b)

FIGURE 4: SEM images of corrosion products of Zn-5Al and Zn-5Al-0.5 Mg-0.08Si coatings ((a) Zn-5Al coating, (b) Zn-5Al-0.5Mg-0.08Si coating). 


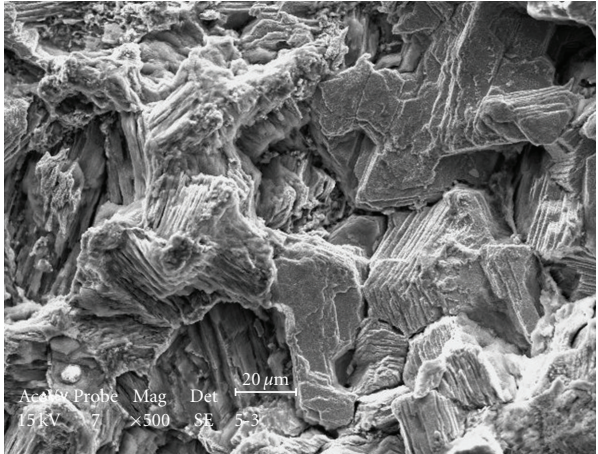

(a)

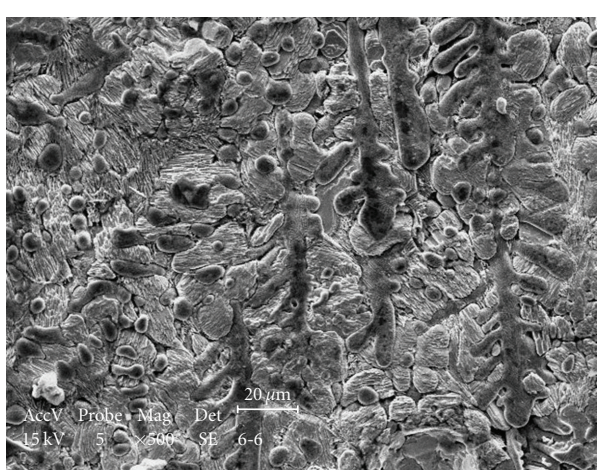

(b)

FiguRE 5: SEM images of coatings surface after removing the corrosion products of neutral salt spray test ((a) Zn-5Al coating, (b) Zn-5Al$0.5 \mathrm{Mg}-0.08 \mathrm{Si}$ coating).

accelerated. The corrosion process of $\mathrm{Zn}-5 \mathrm{Al}$ is dominated by crystal boundary and exfoliation corrosion. But the surface of $\mathrm{Zn}-5 \mathrm{Al}-0.5 \mathrm{Mg}-0.08 \mathrm{Si}$ coating was almost flat, as given in Figure 5(b), so the corrosion process of $\mathrm{Zn}-5 \mathrm{Al}$ $0.5 \mathrm{Mg}-0.08 \mathrm{Si}$ coating is dominated by uniform corrosion. It can be concluded that the addition of $\mathrm{Mg}$ can effectively restrain crystal boundary and exfoliation corrosion, which is an important reason for the improvement in corrosion resistance of $\mathrm{Zn}-5 \mathrm{Al}-0.5 \mathrm{Mg}-0.08 \mathrm{Si}$ coating.

3.5. Corrosion Resistance of Coatings. After neutral salt spray test, the corrosion products were dissolved with saturated ammonium acetate solution. The corrosion rates of $\mathrm{Zn}-5 \mathrm{Al}$ and $\mathrm{Zn}-5 \mathrm{Al}-0.5 \mathrm{Mg}-0.08 \mathrm{Si}$ coatings were measured by weight loss method were 0.5832 and $0.0634 \mathrm{~g} \cdot \mathrm{m}^{-2} \cdot \mathrm{h}^{-1}$, respectively. So, the addition of $\mathrm{Mg}$ can enhance corrosion resistance of $\mathrm{Zn}-5 \mathrm{Al}$ coating markedly with a factor of 9.2, which shows a good application prospect for $\mathrm{Zn}-5 \mathrm{Al}-0.5 \mathrm{Mg}-0.08 \mathrm{Si}$ coating in the future.

\section{Conclusions}

(1) After adding of $\mathrm{Mg}$ to the $\mathrm{Zn}-5 \mathrm{Al}$ coating, the grain is refined significantly.

(2) The addition of $\mathrm{Mg}$ to $\mathrm{Zn}-5 \mathrm{Al}$ coating can promote the conversion process from $\mathrm{Zn}(\mathrm{OH})_{2}$ to $\mathrm{Zn}_{5}(\mathrm{OH})_{8} \mathrm{Cl}_{2} \cdot \mathrm{H}_{2} \mathrm{O}$.

(3) The corrosion products of $\mathrm{Zn}-5 \mathrm{Al}-0.5 \mathrm{Mg}-0.08 \mathrm{Si}$ coating is very compact and the size is fine. It can prevent corrosion media effectively.

(4) The corrosion resistance of $\mathrm{Zn}-5 \mathrm{Al}-0.5 \mathrm{Mg}-0.08 \mathrm{Si}$ coating is dramatically improved with a factor of 9.2 compared with that of $\mathrm{Zn}-5 \mathrm{Al}$.

\section{Acknowledgments}

The present work is supported by the Fundamental Research Funds for the Central Universities (N090602009 and N100402010), Education Department of Liaoning Province of China (2008T239 and LT2010036), Science Foundation of
Shenyang (F10-205-1-20), and Key Projects in the National Science \& Technology Pillar Program during the Eleventh Five-Year Plan Period (2009BAE80B01).

\section{References}

[1] T. Prosek, A. Nazarov, U. Bexell, D. Thierry, and J. Serak, "Corrosion mechanism of model zinc-magnesium alloys in atmospheric conditions," Corrosion Science, vol. 50, no. 8, pp. 2216-2231, 2008.

[2] S. Schürz, G. H. Luckeneder, M. Fleischanderl et al., "Chemistry of corrosion products on $\mathrm{Zn}-\mathrm{Al}-\mathrm{Mg}$ alloy coated steel," Corrosion Science, vol. 52, no. 10, pp. 3271-3279, 2010.

[3] J. Elvins, J. A. Spittle, J. H. Sullivan, and D. A. Worsley, “The effect of magnesium additions on the microstructure and cut edge corrosion resistance of zinc aluminium alloy galvanised steel," Corrosion Science, vol. 50, no. 6, pp. 1650-1658, 2008.

[4] M. Dutta, A. K. Halder, and S. B. Singh, "Morphology and properties of hot dip $\mathrm{Zn}-\mathrm{Mg}$ and $\mathrm{Zn}-\mathrm{Mg}$-Al alloy coatings on steel sheet," Surface and Coatings Technology, vol. 205, no. 7, pp. 2578-2584, 2010.

[5] O. de Rincón, A. Rincón, M. Sánchez et al., "Evaluating Zn, Al and $\mathrm{Al}-\mathrm{Zn}$ coatings on carbon steel in a special atmosphere," Construction and Building Materials, vol. 23, no. 3, pp. 14651471, 2009.

[6] R. P. Edavan and R. Kopinski, "Corrosion resistance of painted zinc alloy coated steels," Corrosion Science, vol. 51, no. 10, pp. 2429-2442, 2009.

[7] L. Guzman, G. K. Wolf, and G. M. Davies, "PVD-IBAD zinc coating development for automotive application," Surface and Coatings Technology, vol. 174-175, pp. 665-670, 2003.

[8] P. Volovitch, C. Allely, and K. Ogle, "Understanding corrosion via corrosion product characterization: I. Case study of the role of $\mathrm{Mg}$ alloying in $\mathrm{Zn}-\mathrm{Mg}$ coating on steel," Corrosion Science, vol. 51, no. 6, pp. 1251-1262, 2009.

[9] B. Wattiez, A. F. Gourgues, A. Deschamps, A. Roemer, and Z. Zermout, "Experimental investigation of microstructure and ageing behaviour of bulk $\mathrm{Zn}-(1-18) \mathrm{wt} \% \mathrm{Al}-(0-0.06) \mathrm{wt} \% \mathrm{Mg}$ alloys," Materials Science and Engineering A, vol. 527, no. 2930, pp. 7901-7911, 2010.

[10] F. Rosalbino, E. Angelini, D. Macciò, A. Saccone, and S. Delfino, "Influence of rare earths addition on the corrosion 
behaviour of $\mathrm{Zn}-5 \% \mathrm{Al}$ (Galfan) alloy in neutral aerated sodium sulphate solution," Electrochimica Acta, vol. 52, no. 24, pp. 7107-7114, 2007.

[11] Q. Li, Y.-Z. Zhao, Q. Luo, S.-L. Chen, J.-Y. Zhang, and K.C. Chou, "Experimental study and phase diagram calculation in Al-Zn-Mg-Si quaternary system," Journal of Alloys and Compounds, vol. 501, no. 2, pp. 282-290, 2010.

[12] D. Yang, J. S. Chen, Q. Han, and K. R. Liu, "Effects of lanthanum addition on corrosion resistance of hot-dipped galvalume coating," Journal of Rare Earths, vol. 27, no. 1, pp. 114-118, 2009.

[13] T. Ishikawa, M. Ueda, K. Kandori, and T. Nakayama, "Air permeability of the artificially synthesized $\mathrm{Zn}-\mathrm{Al}-\mathrm{Mg}$ alloy rusts," Corrosion Science, vol. 49, no. 6, pp. 2547-2556, 2007.

[14] Q. F. Zhang, B. J. Liu, and J. Z. Huang, Modern Continuous Hot-Dip Galvanizing of Hot Steel Strip, Metallurgical Industry Press, Beijing, China, 2007.

[15] L. Zhu, Hot Dip Galvanized Steel, Chemical Industry Press, Beijing, China, 2008.

[16] H. Xu, Study on the Process and Anticorrosion Mechanism of Hot Dipping $\mathrm{Zn}-\mathrm{Al}-\mathrm{Mg}$ Alloy Coating, ShanDong University, Jinan, China, 2009.

[17] X. Y. Liu, S. Miao, F. Liu et al., "A survey of corrosion resistance of a new type of hot-dip zinc alloy," Shandong Scienc, vol. 22, no. 5, p. 36, 2009.

[18] H. F. Zhong, B. J. Liu, and Q. I. F. Zhang, "The development of hot-dip galvanized strip technology abroad," Corrosion and Protection, vol. 23, no. 11, pp. 474-478, 2002.

[19] H. Shindo, T. Okada, K. Asai, K. Nishimura, and N. Nishimura, "Developments and properties of $\mathrm{Zn}-\mathrm{Mg}$ galvanized steel sheet "DYMAZINC" having excellent corrosion resistance," Nippon Steel Technical Report, no. 79, pp. 63-67, 1999.

[20] K. Nishimura, H. Shindo, K. Kato, and Y. Morimoto, "Microstructure and corrosion behaviour of $\mathrm{Zn}-\mathrm{Mg}-\mathrm{Al}$ hotdip galvanized steel sheet," in Proceedings of the International Conference on Zinc and Zinc Alloy Coated Steel, pp. 437-442, Chiba, Japan, 1998.

[21] T. Ishikawa, K. Matsumoto, A. Yasukawa, K. Kandori, T. Nakayama, and T. Tsubota, "Influence of metal ions on the formation of artificial zinc rusts," Corrosion Science, vol. 46, no. 2, pp. 329-342, 2004.

[22] S. Yamamoto, F. Kumon, T. Taomoto, and H. Entani, "Corrosion Resistance of pre-painted $\mathrm{Zn}-6 \% \mathrm{Al}-3 \% \mathrm{Mg}$ alloy coated steel sheet," in Proceedings of the International Conference on Zinc and Zinc Alloy Coated Steel, pp. 659-664, Osaka, Japan, 2007. 

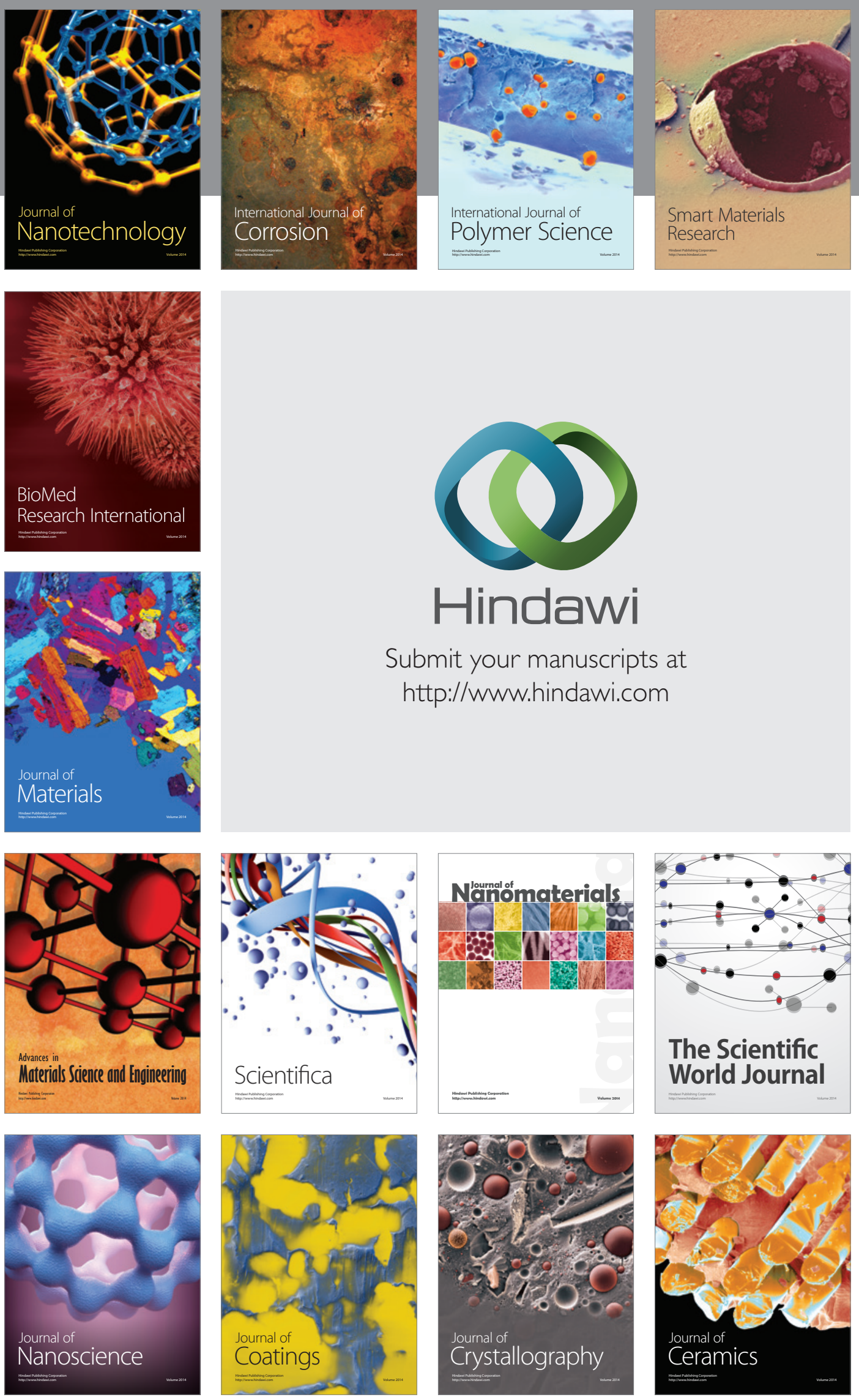

The Scientific World Journal

Submit your manuscripts at

http://www.hindawi.com

\section{World Journal}

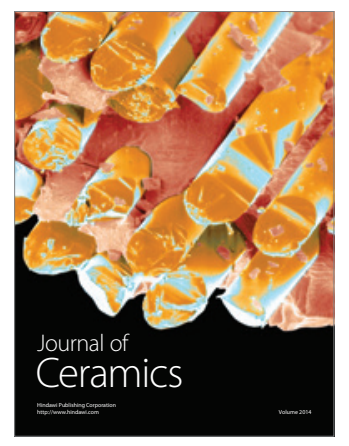

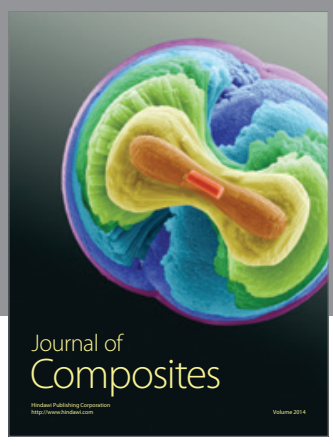
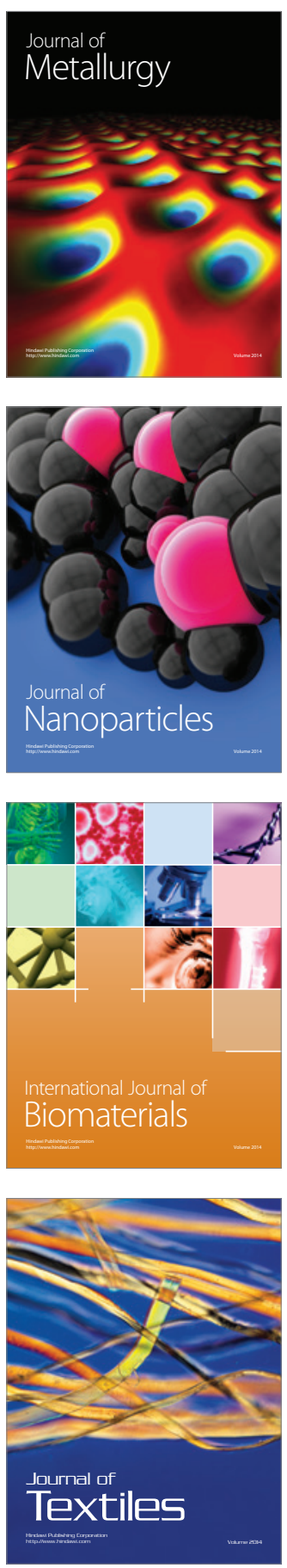